\title{
MODEL PENGATURAN ANTI OBESITAS DALAM RANGKA PENGUATAN SERTA PENINGKATAN DERAJAT KESEHATAN MASYARAKAT DI INDONESIA
}

\author{
I Nyoman Bagiastra ${ }^{1}$, Ni Made Ari Yuliartini Griadhi ${ }^{2}$ \\ ${ }^{1,2}$ Fakultas Hukum, Universitas Udayana, Indonesia \\ e-mail: nyomanbagiastra@unud.ac.id
}

\begin{abstract}
Abstrak
Secara regulasi, sejatinya pemerintah Indonesia menyadari akan bahaya dampak serta resiko yang ditimbulkan dari obesitas. Terlihat dikeluarkannya Peraturan Menteri Kesehatan Nomor 30 Tahun 2013 Tentang Pencantuman Informasi Kandungan Gula, Garam dan Lemak Serta Pesan Kesehatan untuk Pangan Olahan dan Pangan Siap Saji yang selanjutnya diamandemen dengan Permenkes Nomor 63 Tahun 2015. Di Negara maju yaitu Amerika dan Jepang memiliki program khusus serta regulasi terkait penanganan obesitas. Malaysia merupakan yang menjadi negara pertama di Asia yang memiliki undang-undang antiobesitas agar obesitas menurun di masyarakatnya. Roscoe Pound menyatakan hukum dapat berfungsi sebagai alat merekayasa masyarakat (law as a tool of social engineering). Hukum dalam arti kaedah atau peraturan hukum memang bisa berfungsi sebagai alat (pengatur) atau sarana pembangunan dalam arti penyalur arah kegiatan manusia ke arah yang dikehendaki oleh pembangunan. Prevalensi obesitas di Indonesia mengalami peningkatan mencapai tingkat yang membahayakan. Intervensi pemerintah dalam hal ini sangat dibutuhkan, yatu dengan membuat suatu regulasi sebagai alat untuk merekayasa sosial terkait permasalahan obesitas di Indonesia.
\end{abstract}

Kata kunci : Pengaturan, Obesitas, Kesehatan Masyarakat

\begin{abstract}
By regulation, the Indonesian government is actually aware of the dangers of the impacts and risks arising from obesity. Seen the issuance of Minister of Health Regulation No. 30 of 2013 concerning Inclusion of Information on Sugar, Salt and Fat Content and Health Messages for Processed Foods and Ready-to-eat Foods, which are subsequently amended with Permenkes Number 63 of 2015. In developed countries, namely the United States and Japan have special programs and regulations related to handling obesity. Malaysia is the first country in Asia to have anti-obesity laws to reduce obesity in its society. Roscoe Pound states that law can function as a tool for engineering society (law as a tool of social engineering). Law in the sense of a method or legal regulation can indeed function as a tool (regulator) or a means of development in the sense of channeling the direction of human activity in the direction desired by development. The prevalence of obesity in Indonesia has increased to reach dangerous levels. Government intervention in this case is needed, namely by making a regulation as a tool to manipulate social issues related to obesity in Indonesia.
\end{abstract}

Keywords : Arrangement, Obesity, Community Health 


\section{PENDAHULUAN}

Keinginan pendirian negeri dalam pembukaan Undang-Undang Dasar 1945, dimana seharusnya Negara Kesatuan Republik Indonesia (NKRI) dibangun untuk melindungi rakyat, dalam praktik sektor kesehatan, rakyat tidak terlindungi secara baik, khususnya masyarakat miskin. Hidup sehat merupakan hak paling mendasar dan prasyarat seseorang bisa berfungsi normal. Fungsi normal seseorang adalah tumbuh kembang, bermain ketika bayi sampai usia sekolah, belajar ketika usia sekolah, bekerja setelah usia sekolah, hidup sehat membina anak cucu ketika usia lanjut (Hasbullah Thabrany, 2015). Menurut Diana (2013) Pencapaian Indeks Pembangunan Manusia di dunia tidak terlepas dari segi peningkatan kualitas kesehatan. Namun, saat ini masih banyak masalah gizi yang dapat memengaruhi kualitas kesehatan salah satunya adalah masalah kegemukan. Pencegahan epidemi kegemukan merupakan salah satu tantangan besar gizi dan kesehatan masyarakat baik di negara maju maupun negara berkembang.

Obesitas atau kegemukan untuk sebagian orang sejatinya merupakan suatu permasalahan yang harus ditangani secara serius. Selain mengganggu penampilan dari segi estetika, obesitas juga menyebabkan berbagai macam masalah kesehatan. Masalah kesehatan yang disebabkan oleh obesitas ini beragam mulai dari hipertensi, penyakit jantung koroner hingga stroke. Penyebabnya bermacam-macam di antaranya adalah genetis, faktor lingkungan, faktor psikis, kelainan atau penyakit seperti hipotiroidisme, dan aktivitas fisik. Penyebab tersering obesitas adalah faktor lingkungan yaitu pola makan dan gaya hidup yang tidak sehat. Obesitas di Indonesia sudah mulai dirasakan secara nasional dengan semakin meningginya angka kejadiannya. Selama ini kegemukan di Indonesia belum menjadi sorotan prioritas karena masih disibukkan terhadap masalah kekurangan gizi (Kemenkes 2010). Obesitas merupakan suatu keadaan fisiologis akibat dari penimbunan lemak secara berlebihan di dalam tubuh. Saat ini gizi lebih yang tidak terkontrol dan obesitas merupakan epidemik di negara maju, seperti Inggris, Brasil, Singapura dan dengan cepat berkembang di negara berkembang, terutama populasi kepulauan Pasifik dan negara Asia tertentu. Prevalensi obesitas meningkat secara signifikan dalam beberapa dekade terakhir dan dianggap oleh banyak orang sebagai masalah kesehatan masyarakat yang utama (Sarah EB and the Expert Committee 2011). Menurut Husnah
(2012) Obesitas bukan sekedar masalah Kesehatan, melainkan masalah kesadaran. Dulu kegemukan identik dengan kemakmuran, akan tetapi sekarang kegemukan merupakan suatu kelainan atau penyakit. Obesitas saat ini disebut sebagai the New World Syndrome, angka kejadiannya terus meningkat dimanamana. Di seluruh dunia, kini dilaporkan ada lebih dari satu miliar orang dewasa dengan berat badan lebih (gemuk), dan paling sedikit ada 300 juta orang yang masuk kategori obesitas (BMI di atas 30). Di Amerika Serikat dan negara-negara maju di Eropa Barat misalnya, hampir dua per tiga penduduk mengidap kegemukan; sedangkan di Indonesia, dapat dikatakan lebih dari seperempat penduduk memiliki berat badan berlebihan.

Menjadi suatu keharusan bagi Pemerintah (baik pemerintah pusat maupun daerah) dan penentu kebijakan lainnya untuk menetapkan kebijakan dan rencana kegiatan yang menjamin ketersediaan (availabillity) dan keterjangkauan (accessability) pemeliharaan kesehatan untuk semua secepat mungkin demi kesejahteraan masyarakat secara adil dan beradab (Sri. Astuti. Suparmanto 2010). Menurut Mantan Menteri Kesehatan, Farid Anfasa Moeloek, Pembangunan yang tidak mengindahkan dampak positif dan dampak negatif terhadap kesehatan manusia, kesehatan lingkungan, kesehatan sosial, dan kesehatan budaya merupakan bentuk dari pelanggaran hak asasi manusia (Farid Anfasa Moeloek 2003).

Secara regulasi, sejatinya pemerintah Indonesia menyadari akan bahaya dampak serta resiko yang ditimbulkan dari obesitas. Terlihat dikeluarkannya Peraturan Menteri Kesehatan Nomor 30 Tahun 2013 Tentang Pencantuman Informasi Kandungan Gula, Garam dan Lemak Serta Pesan Kesehatan untuk Pangan Olahan dan Pangan Siap Saji yang selanjutnya diamandemen dengan Permenkes Nomor 63 Tahun 2015.

Roscoe Pound menyatakan hukum dapat berfungsi sebagai alat merekayasa masyarakat (law as a tool of social engineering). Hukum dalam arti kaedah atau peraturan hukum memang bisa berfungsi sebagai alat (pengatur) atau sarana pembangunan dalam arti penyalur arah kegiatan manusia ke arah yang dikehendaki oleh pembangunan. 


\section{METODE}

Dalam melakukan penelitian ilmiah ini termasuk dalam didukung oleh metode tertentu, sehingga penelitian tersebut dapat berlangsung secara terencana dan teratur. Van Peursen menterjemahkan pengertian metode secara harfiah, mula-mula metode diartikan sebagai suatu jalan yang harus ditempuh menjadi penyelidikan atau penelitian, berlangsung menurut suatu rencana tertentu (Johnny Ibrahim 2006). Penelitian adalah merupakan suatu kegiatan ilmiah yang berkaitan dengan analisa dan kontruksi yang dilakukan secara metodologis, sistematis, dan konsisten (Soerjono Soekanto 1984). Sementara penelitian hukum adalah suatu proses untuk menemukan aturan hukum, prinsip-prinsip hukum, maupun doktrindoktrin hukum, guna menjawab isu hukum yang dihadapi, sehingga penelitian hukum dilakukan untuk menghasilkan argumentasi, teori atau konsep baru sebagai preskripsi dalam penyelesaian masalah yang dihadapi (Peter Mahmud Marzuki 2009).

Penelitian yang dilakukan kaitannya dengan penelitian ini termasuk jenis penelitian hukum normatif, yaitu penelitian hukum kepustakaan atau penelitian hukum yang didasarkan pada data sekunder (Soerjono Soekanto 1985). Dengan demikian dapat dipahami bahwa penelitian hukum normatif memfokuskan obyek kajian pada ketentuanketentuan hukum positif, lalu mengarah pada makna dari azas hukum. Penelitian hukum normatif terhadap pengkajian (analisis) dimulai dari perangkat-perangkat pasal-pasal hukum positif terkandung konsep-konsep eksplanasi dan sifat dari permasalahan penelitian. Selanjutnya mendalami lapisan ilmu hukum (dogmatik hukum, teori hukum, dan filsafat hukum) (Hadin Mudjad HM. dan Nunuk Nuswardani 2012).

Penelitian kepustakaan yaitu penelitian yang dilakukan dengan mencari, mempelajari dan mengumpulkan data sekunder yang berhubungan dengan obyek penelitian, dengan bantuan buku, literatur, peraturan perundang undangan dan dokumen-dokumen yang terdiri dari :

a. Bahan Hukum Primer

Bahan hukum primer yaitu bahan hukum yang mengikat (Soerjono Soekanto dan Sri Mamudji 2006) Bahan hukum primer dalam penelitian ini terdiri atas :

1. UU No. 36 Tahun 2009 Tentang Kesehatan

2. UU No. 18 Tahun 2012 Tentang Pangan.
3. Permenkes RI nomor 30 tahun 2013 tentang Pencantuman Informasi Gula, Garam, dan Lemak Serta Pesan Kesehatan Untuk Pangan Olahan dan Pangan Siap Saji.

4. PP No 69 Tahun 1999 tentang Label dan Iklan Pangan.

5. PP No. 28 Tahun 2004 tentang Keamanan, mutu, dan Gizi Pangan.

b. Bahan Hukum Sekunder

"Bahan hukum sekunder ialah bahan hukum yang mejelaskan bahan hukum primer". Terutama buku-buku hukum termasuk skripsi, thesis, disertasi hukum dan jurnal jurnal hukum,(termasuk yang on-line). Bahan hukum sekunder berguna untuk meberikan petunjuk kearah mana peneliti akan melangkah.

c. Bahan Hukum Tersier

"Bahan hukum tersier adalah bahan hukum yang memberikan petunjuk maupun penjelasan terhadap bahan hukum primer dan bahan hukum sekunder" (Peter Mahmud Marzuki 2005) yang terdiri dari Kamus BesarBahasa Indonesia, Kamus Hukum BelandaIndonesia, Kamus Inggris-Indonesia.

Untuk memperoleh bahan hukum yang diperlukan dalam penelitian kepustakaan, maka dilakukan studi dokumen yaitu mempelajari bahan-bahan hukum primer, sekunder dan tersier. Teknik pengumpulan data yang akan digunakan dalam penelitian ini dilakukan dengan cara studi kepustakaan. Studi kepustakaan dilakukan untuk mengumpulkan data sekunder melalui pengkajian terhadap peraturan perUndangUndangan, literatur-literatur, tulisan-tulisan para pakar hukum, bahan kuliah, yang berkaitan dengan penelitian ini. Pengolahan, analisis dan konstruksi data penelitian hukum normatif dapat dilakukan dengan cara melakukan analisis terhadap kaidah hukum dan kemudian konstruksi dilakukan dengan cara memasukkan pasal-pasal kedalam kategori-kategori atas dasar pengertianpengertian dasar dari sistem hukum tersebut. Data yang diperoleh melalui studi kepustakaan kemudian dianalisis berdasarkan metode kualitatif, yaitu dengan melakukan :

a. Menemukan konsep-konsep yang terkandung dalam bahan-bahan hukum (konseptualisasi) yang dilakukan dengan cara memberikan interpretasi terhadap bahan hukum tersebut ; 
b. Mengelompokkan konsep-konsep atau peraturan-peraturan yang sejenis atau berkaitan;

c. Menemukan hubungan di antara pelbagai kategori atau peraturan kemudian diolah ;

d. Menjelaskan dan menguraikan hubungan di antara pelbagai kategori atau peraturan perundang-undangan, kemudian dianalisis secara deskriptif kualitatif. Sehingga mengungkapkan hasil yang diharapkan dan kesimpulan atas permasalahan.

\section{HASIL DAN PEMBAHASAN}

Obesitas adalah kelebihan lemak dalam tubuh, yang umumnya ditimbun dalam jaringan subkutan (bawah kulit), sekitar organ tubuh dan kadang terjadi perluasan ke dalam jaringan organnya (Khomsan, A 2003)

Obesitas merupakan keadaan yang menunjukkan ketidakseimbangan antara tinggi dan berat badan akibat jaringan lemak dalam tubuh sehingga terjadi kelebihan berat badan yang melampaui ukuran ideal (Kurniawati, Dwi Hera 2008).

Dengan demikian tiap orang perlu memperhatikan banyaknya masukan makanan (disesuaikan dengan kebutuhan tenaga seharihari) dan aktivitas fisik yang dilakukan. Perhatian lebih besar mengenai kedua hal ini terutama diperlukan bagi mereka yang kebetulan berasal dari keluarga obesitas, berjenis kelamin wanita, pekerjaan banyak duduk, tidak senang melakukan olahraga, serta emosionalnya labil.

Berdasarkan kondisi selnya, kegemukan dapat digolongkan Dalam beberapa tipe yaitu : 1) Tipe Hiperplastik, adalah kegemukan yang terjadi karena jumlah sel yang lebih banyak dibandingkan kondisi normal, tetapi ukuran sel-selnya sesuai dengan ukuran sel normal terjadi pada masa anak-anak.Upaya menurunkan berat badan ke kondisi normal pada masa anak-anak akan lebih sulit. 2) Tipe Hipertropik, kegemukan ini terjadi karena ukuran sel yang lebih besar dibandingkan ukuran sel normal. Kegemukan tipe ini terjadi pada usia dewasa dan upaya untuk menurunkan berat akan lebih mudah bila dibandingkan dengan tipe hiperplastik. 3) Tipe Hiperplastik dan Hipertropik kegemukan tipe ini terjadi karena jumlah dan ukuran sel melebihi normal. Kegemukan tipe ini dimulai pada masa anak - anak dan terus berlangsung sampai setelah dewasa. Upaya untuk menurunkan berat badan pada tipe ini merupakan yang paling sulit, karena dapat beresiko terjadinya komplikasi penyakit, seperti penyakit degeneratif. Berdasarkan penyebaran lemak didalam tubuh, ada dua tipe obesitas yaitu:

a). Tipe buah apel (Adroid), pada tipe ini ditandai dengan pertumbuhanlemak yang berlebih dibagian tubuh sebelah atas yaitu sekitar dada, pundak, leher, dan muka. Tipe ini pada umumnya dialami pria dan wanita yang sudah menopause. Lemak yang menumpuk adalah lemak jenuh.

b). Tipe buah pear (Genoid), tipe ini mempunyai timbunan lemak pada bagian bawah, yaitu sekitar perut, pinggul, paha, dan pantat. Tipe ini banyak diderita oleh perempuan. Jenis timbunan lemaknya adalah lemak tidak jenuh (Budiyanto, MAK 2002).

Salah satu upaya pemerintah dalam upayanya menanggulangi obeistas dan gizi buruk yaitu dengan Positive Deviance (PD) atau penyimpangan positive adalah sebuah program baru di dalam dunia kesehatan, yang bertujuan untuk menangani kasus gizi buruk atau gizi kurang bagi anak-anak Balita yang ada di seluruh Indonesia. Disebut dengan penyimpangan positive karena anak-anak penderita gizi buruk yang berada di satu lingkungan bisa mencontoh perilaku hidup sehat anak-anak yang tidak menderita gizi buruk.Program PD ini lebih mengembangkan konsep pemberdayaan dan keterlibatan masyarakat secara penuh untuk mengatasi masalah gizi buruk, sangat jauh berbeda dengan program PMT (Pemberian Makanan Tambahan) yang dikembangkan oleh pemerintah. Program PMT sangat tidak efektif karena masyarakat tidak dilibatkan secara penuh dalam program tersebut, bahkan cenderung membuat masyarakat manja dan memiliki ketergantungan sangat tinggi terutama bagi keluarga penderita gizi buruk. Di samping itu juga, program PMT sangat mubazir dalam hal pembiayaan, karena semua keluarga penderita gizi buruk selalu berharap untuk mendapat bantuan. Itu sebabnya program PD perlu mendapat perhatian pemerintah (Depkes) untuk diadopsi dalam rangka mengatasi gizi buruk di masyarakat.

Disamping itu pula, upaya pemerintah adalah dengan upaya peningkata di sektor kesehatan kuratif dan rehabilitatif sejak dini: 1) Penemuan aktif dan rujukan kasus gizi buruk, 2) Perawatan balita gizi buruk, 3) Pendampingan balita gizi buruk pasca perawatan

Upaya Kesehatan Promotif dan Preventif: 1) Pendidikan (penyuluhan) gizi melalui promosi kadarzi, 2) Revitalisasi 
posyandu, 3) Pemberian suplementasi gizi, 4) Pemberian MP - ASI bagi balita gakin

Kerangka Kerja Pencegahan Dan Penanggulangan Gizi Buruk Sistem Kewaspadaan Pangan dan Gizi Komponen SKPG: 1) Keluarga, 2) Masyarakat dan Lintas Sektor, 3) Pelayanan Kesehatan

$$
\text { Peran }
$$$$
\text { Keluarga: }
$$

Penyuluhan/Konseling Gizi: a. ASI eksklusif dan MP-ASI; b. Gizi seimbang; 2) Pola asuh ibu dan anak, 3) Pemantauan pertumbuhan anak, 4) Penggunaan garam beryodium; 5) Pemanfaatan pekarangan; 6) Peningkatan daya beli keluarga miskin; 7) Bantuan pangan darurat: a. PMT balita, ibu hamil, b. Raskin

Peran Masyarakat dan Lintas Sektor: 1) Mengaktifkan Posyandu: SKDN; 2) Semua balita mempunyai KMS; 3) Penimbangan balita (D); 4) Konseling; 5) Suplementasi gizi; 6) Pelayanan kesehatan dasar; 7) Berat badan naik (N) sehat dikembalikan ke peran keluarga; 8) BB Tidak naik (T1), Gizi kurang diberikan PMT Penyuluhan dan Konseling; 9) Berat badan Tidak naik (T2), BGM, Gizi buruk, sakit, dirujuk ke RS atau Puskesmas

Peran Pelayanan Kesehatan: 1) Mengatasi masalah medis yang mempengaruhi gizi buruk; 2) Balita yang sembuh dan perlu PMT, perlu dikembalikan ke Pusat Pemulihan Gizi untuk diberikan PMT; 3) Balita yang sembuh, dan tidak perlu PMT, dikembalikan kepada masyarakat.

Menurunnya prevalensi Kurang Energi Protein (KEP) menjadi setinggi-tingginya $15 \%$ dan gizi buruk menjadi setinggi-tingginya 2,5 \% pada tahun 2014.

Tujuan Khusus: 1) Meningkatnya cakupan deteksi dini gizi buruk melalui penimbangan balita di Posyandu, Puskesmas dan jaringannya; 2) Meningkatnya cakupan suplementasi gizi terutama pada kelompok penduduk rawan dan keluarga miskin; 3) Meningkatnya jangkauan dan kualitas tata laksana kasus gizi buruk di Rumah Tangga, Puskesmas dan Rumah Sakit; 4) Meningkatnya kemampuan dan ketrampilan keluarga dalam menerapkan Keluarga Sadar Gizi (KADARZI); 5) Berfungsinya Sistem Kewaspadaan Pangan Dan Gizi (SKPG).

Kebijakan Operasional Pencegahan Dan Penanggulangan Gizi Buruk: 1) Merupakan Program Nasional: Perencanaan, pelaksanaan, pemantauan dan evaluasi dilaksanakan secara berkesinambungan antara pusat dan daerah; 2) Pendekatan komprehensif: Mengutamakan upaya pencegahan dan upaya peningkatan, yang didukung upaya pengobatan dan pemulihan; 3) Semua kabupaten/kota secara terus menerus melakukan upaya pencegahan dan penanggulangan gizi buruk, dengan koordinasi lintas instansi/dinas dan organisasi masyarakat; 4) Menggalang kemitraan antara pemerintahan, dunia usaha dan masyarakat di berbagai tingkat; 5) Pendekatan Pemberdayaan masyarakat serta keterlibatan dalam proses pengambilan keputusan (Ibid, Budiyanto, MAK 2002).

Berdasarkan data Riskesdas terjadi peningkatan prevalensi obesitas pada tiap tahap kehidupan. Kejadian peningkatan Gizi lebih ini akan memberikan beban pembangunan bidang kesehatan yang semakin berat dengan masih adanya masalah gizi kurang. Makin meningkatnya masalah kesehatan yang bersumber dari masalah gizi lebih perlu diantisipasi dengan melakukan perubahan kebijakan yang mendasar dalam upaya pelayanan kesehatan. Dengan terbatasnya sumberdaya yang ada dan semakin terbatasnya kemampuan pemerintah menyediakan anggaran disaat beban pembangunan kesehatan meningkat maka kebijakan berimbang dan simultan dengan meningkatkan partisipasi masyarakat secara luas merupakan hal yang krusial dan pendekatan yang sensible untuk kebijakan pencegahan dan penanggulangan kegemukan dan obesitas.

Pencegahan dan Penanggulangan kegemukan dan obesitas pada anak sekolah merupakan suatu upaya komprehensif yang melibatkan stakeholder yang ada di wilayah. Stakeholders mempunyai peran sesuai dengan tanggung jawab dan kewenangan, melalui koordinasi dengan kepala Puskesmas.

Usaha pencegahan dimulai dari lingkungan keluarga, sekolah, masyarakat dan fasilitas pelayanan kesehatan. Lingkungan sekolah merupakan tempat yang baik untuk pendidikan kesehatan yang dapat memberikan pengetahuan, keterampilan serta dukungan sosial dari warga sekolah. Pengetahuan, keterampilan serta dukungan sosial ini memberikan perubahan perilaku makan sehat yang dapat diterapkan dalam jangka waktu lama. Tujuan pencegahan ini adalah terjadinya perubahan pola dan perilaku makan meliputi meningkatkan kebiasaan konsumsi buah dan sayur, mengurangi konsumsi makanan dan minuman manis, mengurangi konsumsi makanan tinggi energi dan lemak, mengurangi konsumsi junk food, serta peningkatan aktivitas fisik dan mengurangi sedentary life style.

Kementerian Kesehatan Malaysia baru-baru ini menyatakan komitmennya untuk menekan angka kejadian obesitas di negara 
mereka dengan membentuk suatu undangundang anti-obesitas yang akan diterapkan pada tahun 2020. Hal itu disampaikan oleh Direktur Jenderal Kesehatan Malaysia Datuk dr Hasan Abdul Rahman. Meski terlihat kontroversial dan sulit untuk diimplementasikan, dikatakan bahwa pihaknya akan terus berupaya menekan obesitas dengan edukasi dan kampanye kesadaran kepada masyarakat.

Undang-undang tersebut akan efektif membantu mengurangi tingkat obesitas dan beberapa penyakit terkait lainnya. Ketika seseorang kelebihan berat badan atau obesitas, risiko menderita diabetes, serangan jantung, hipertensi, dan kanker akan lebih tinggi. Hukum anti-obesitas akan menjadi cara yang baik untuk mempromosikan pekerja sehat dan bangsa yang sehat. Dengan berat badan ideal, risiko terkena penyakit akan berkurang sehingga meningkatkan kualitas kerja dan mengurangi uang yang dihabiskan untuk pengobatan.

Survei menunjukkan bahwa hampir 90 persen orang dewasa memiliki satu atau lebih penyakit akibat kelebihan berat badan, yaitu sebanyak 20,6 persen memiliki kolesterol tinggi, 32,2 persen tekanan darah tinggi (hipertensi), dan 14,9 persen diabetes. Peraturan tersebut akan meliputi pengukuran lingkar pinggang karyawan berusia 40-74 tahun, sebagai bagian dari pemeriksaan kesehatan tahunan. Selain itu, sebuah perusahaan akan mendapatkan hukuman jika lingkar pinggang karyawan melebihi 33,5 inci pada pria dan 35,4 inci untuk wanita. Karyawan yang gagal untuk mengurangi ukuran pinggang akan menjalani konseling. Perusahaan harus memberikan kontribusi program kesehatan untuk karyawan yang menderita obesitas. Datuk dr Hasan Abdul Rahman mengatakan bahwa pemberlakuan hukum tersebut tidak bermaksud mendiskriminasi orang dengan berat badan berlebihan, tetapi untuk memastikan bahwa kesehatan para karyawan dihargai dan mengadopsi gaya hidup sehat.

Menurut pemahaman di negara Jepang sebagai Negara yang maju, obesitas berkaitan dengan tingkat kemiskinan dan pendidikan di sebuah negara. mereka punya pengetahuan soal nutrisi, itu membuat asupan warga Jepang rata-rata lebih sedikit, karena mereka mengetahui bagaimana mencukupi nustrisi untuk memenuhi kebutuhan tubuh. masyarakat Jepang juga benar-benar memperhatikan makanan. Mereka banyak mengonsumsi sayur, ikan dan daging sehingga gizi mereka tercukupi. Paling penting termyata warga Jepang jarang yang memiliki kendaraan dan lebih suka naik transportasi umum atau berjalan kaki. Sehingga secara tidak langsung mereka berolahraga setiap hari. Pemerintah Jepang membuat UU Anti Kegemukan yaitu dengan aturan batas pinggang untuk pria maksimal adalah 33.5 inchi, sedangkan untuk wanita adalah 35.4 inchi. Jika melewati batas ini, maka orang tersebut harus melakukan diet jika tidak ingin terkena denda.

Sebagai negara hukum, tentunya hukum menjadi salah satu instrumen penting dalam pembangunan Indonesia. Pembangunan yang di maksudkan tentunya tidak pada fisik semata yang terbatas oleh ruang dan waktu tertentu. Melainkan pembangunan kualitas segenap rakyat Indonesia dalam upaya mencerdaskan kehidupan bangsa yang bersifat proyeksi jauh kedepan. Pada zaman reformasi sekarang ini, hukum di tuntut menjadi panglima bagi kemajuan bengasa, seiring dengan kemajuan demokrasi kita. Namun, dewasa ini hukum cenderung terpasung oleh demokrasi itu sendiri. Demokrasi seharusnya dapat berbanding lurus dengan kedaulatan hukum (Nomokrasi) dalam perjalananya membangun bangsa ini.

Hukum selalu menjadi tumpuan harapan rakyat Indonesia untuk mewujudkan keadilan. Keadilan yang menjadi salah satu dari tujuan hukum seharusnya dapat di praktekan dalam upaya membangun masyarakat, bukan mengadili masyarat dalam pembanguan dengan dalih bahwa kita adalah negara hukum. Peranan hukum dalam membangun masyarakat, berarti juga bahwa kedaulatan hukum berada di tangan rakyat sebagaimana pengertian kedaulatan rayat dalam berdemokrasi. Meskipun dalam penerapan serta penegakannya antar demokrasi dan hukum berbeda.

Secara filosofis apa yang menjadi dasar akan pentingnya dirumuskan dalam bentuk norma yang bersifat mengatur terkait konstruksi hukum serta model pengaturan anti obesitas dalam rangka penguatan serta peningkatan derajat kesehatan masyarakat di Indonesia, Kesehatan merupakan kondisi sejahtera dari badan, jiwa, dan sosial yang memungkin setiap orang produktif secara ekonomis (Ps. 1 point (1) UU Nomor 36 Tahun 2009 tentang Kesehatan). Karena itu kesehatan merupakan dasar dari diakuinya derajat kemanusiaan. Tanpa kesehatan, seseorang menjadi tidak sederajat secara kondisional. Tanpa kesehatan, seseorang tidak akan mampu memperoleh hak-haknya 
yang lain. Seseorang yang tidak sehat dengan sendirinya akan berkurang haknya atas hidup, tidak bisa memperoleh dan menjalani pekerjaan yang layak, tidak bisa menikmati haknya untuk berserikat dan berkumpul serta mengeluarkan pendapat, dan tidak bisa memperoleh pendidikan demi masa depannya. Singkatnya, seseorang tidak bisa menikmati sepenuhnya kehidupan sebagai manusia.

Secara yuridis, Tantangan utama adalah kondisi masyarakat Indonesia yang masih belum keluar dari himpitan krisis sehingga sulit mendapatkan pelayanan kesehatan yang baik. Kemiskinan memang merupakan musuh utama kesehatan. Kondisi ini menyatu dengan trend kesehatan sebagai industri yang seringkali melupakan aspek kesehatan sebagai pelayanan kemanusiaan. Kesehatan menjadi barang yang mahal. Apalagi pengambil kebijakan ternyata juga belum memiliki komitmen dengan tanggung jawabnya terhadap kesehatan. Hal ini dibuktikan dengan minimnya pembiayaan yang dialokasikan untuk sektor kesehatan baik berupa penyediaan sarana dan prasarana maupun jaminan sosial terhadap pelayanan kesehatan. Secara regulasi, Indonesia tidak memiliki peraturan tentang anti obesitas. Wujud perhatian pemerintah dalam tataran promotif dan prevntif masih sangat rendah.

Secara sosiologis, produk hukum yang responsiflah yang dapat di jadikan sarana untuk membangun masyarakat. Namun, dalam prakteknya produk hukum kita jauh dari produk hukum yang responsif. Kebanyakan produk hukum kita bersifat represif. Banyak UndangUndang yang di bentuk berpihak pada kepentingan penguasa dalam melanggengkan kekuasaannya.

Penbentukan hukum yang responsif tidaklah mudah untuk di lakukan di tengah keberagaman karakter masyarakat Indonesia. Namun, kita harus tetap optimis dalam hal menjadikan hukum sebagai sarana pembangunan dan pembaharuan masyarakat. Dengan ideologi Pancasila, dan amanat konstitusi kita UUD 1945 seharusnya kita telah dapat menjadikan hukum sebagai sarana pembaharuan dan pembangunan masyarakat. Namun, dalam prakkteknya hukum kembali tunduk dengan penguasaan atas kepentingan politik penguasa.

Persoalan dalam pembentukan hukum jelas akan berimbas pada proses penegakan hukum. Kalo melihat penegakan hukum di Indonesia saat ini, menurut saya kita belum pantas di katakan sebagai negara yang berdaulat dalam hukum. Dalam hal penegakan hukum, bangsa ini selalu mengalami persoalan diskriminatif terhadap keadilan yang merupakan tujuan hukum. Seharusnya proses penegakan hukum merupakan instrumen penting dalam hal mencapai tujuan hukum, yakni kepastian hukum yang bermuara pada keadilan dan ketertiban.

Model pengaturan anti obesitas di Indonesia bisa mengadopsi regulasi di jepang dan di Malaysia. Mengingat secara kultur terdapat kemiripan. Hal penting yang bisa dilakukan dalam merumuskannya, harus sesuai dengan suasana kebatinan masyarakat Indonesia. Seperti, perlunya control yang sangat ketat terhadap konsumsi gula, karbohidrat dan lainnya yang berpotensi pemicu terhadap obesitas.

\section{PENUTUP}

Pengaturan terhadap segala potensi penyebab obesitas di Indonesia belum terakomodir dengan baik, dapat dilihat dengan minimnya regulasi mengenai control pemeritah terhadap masyarakat dalam tataran promotif dan preventif. Konstruksi model pengaturan anti obesitas di negara maju dan negara berkembang, di Negara jepang dengan ketat menggunakan lingkar pinggang dalam memnentukan obesitas yang dituangkan dalam bentuk peratura, sedngkan Malaysia memiliki kemiripan secara pola dan akan dilaksanakan dan di undangkan tahun 2020. Konstruksi hukum serta model pengaturan anti obesitas dalam rangka penguatan serta peningkatan derajat kesehatan masyarakat di Indonesia, bisa mengadopsi pola regulasi jepang serta yang terpenting adalah perlunya control yang sangat ketat terhadap konsumsi gula, karbohidrat dan lainnya yang berpotensi pemicu terhadap obesitas yang dituangkan dalam peraturan per Undang-undangan di Indonesia.

Disarankan agar segera Indonesia merumuskan regulasi terkait anti obesitas dalam rangka meningkatkan derajat kesehatan masyarakat di Indonesia secara universal.

\section{DAFTAR PUSTAKA}

Ammerman, R, T \& Hersen, M, 1997, Handbook of Prevention and Adolescent. New York : John Wiley \& Sons. Inc.

Diana, Rian, Indah Yuliana, Ghaida Yasmin, dan Hardinsyah. 2013. Faktor Risiko Kegemukan pada Wanita Dewasa Indonesia. Jurnal Gizi dan Pangan, Maret 2013, 8(1) Hal. 1-8. Tersedia 
Pada:

http://jesl.journal.ipb.ac.id/index.php/jgi zipangan/article/viewFile/7226/5647.

Farid Anfasa Moeloek, Pembangunan Berkelanjutan Dalam Peningkatan Derajat Kesehatan Masyarakat, Makalah pada Seminar Pembangunan Nasional Departemen Kehakiman dan Hak Asasi Manusia, 14-18 Juli 2003.

Hasbullah Thabrany, 2015, Jaminan Kesehatan Nasional, PT Raja Grafindo Persada, Jakarta.

Husnah. 2012. Tatalaksana Obesitas. Jurnal Kedokteran Syiah Kuala Volume 12 Nomor 2 Hal. 99-104. Tersedia Pada: http://www.jurnal.unsyiah.ac.id/JKS/arti cle/download/3506/3259.

Kementerian Kesehatan. Laporan Hasil Riset Kesehatan Dasar Indonesia Tahun 2010. Jakarta, 2011.

Kaplan, H, I. et all, 1994, Sipnosis Psikiatri. IImu Pengetahuan Perilaku Psikiatri Klinis. Jakarta: Binarupa Aksara.

Lily Rasjidi, 1990, Dasar-Dasar Filsafat Hukum, PT. Citra Aditya Bakti, Bandung.

Mochtar Kusumaatmadja, 1976, Hukum, Masyarakat dan Pembinaan Hukum Nasional, Bina Cipta, Bandung.

Oku, B.F. , 1990, Seeking Conections in Psykiatry. San Fransisco \& Oxford Jossey-Bass Publischers.

Permenkes RI nomor 30 tahun 2013 tentang Pencantuman Informasi Gula, Garam, dan Lemak Serta Pesan Kesehatan Untuk Pangan Olahan dan Pangan Siap Saji.

PP No 69 Tahun 1999 tentang Label dan Iklan Pangan.

PP No. 28 Tahun 2004 tentang Keamanan, mutu, dan Gizi Pangan.
Sarah EB and the Expert Committee. Expert Committee Recommendations Regarding the Prevention, Assesment, and traetment of Child and Adolescent Overweight and Obesity: Summary Report. J.Pediatrics. 2007;120;S164S192. Available at www.pediatrics.org/cgi/full/120/supple ment_4/S164. Accesed April 1, 2011.

Sri. Astuti. Suparmanto, Pedoman Umum Pelayanan Posyandu, Jakarta, Departemen Kesehatan RI. 2006.

Syahmin, AK, Mengkritisi Hukum Sebaga Sarana Pembaharuan Masyarakat Indonesia, Jurnal Hukum Progresif Volume I Nomor 2, Oktober, 2005.

Sunaryati Hartono, 1982, Hukum Ekonomi Pembangunan Indonesia, Binacipta, Bandung.

UU No. 36 Tahun 2009 Tentang Kesehatan

UU No. 18 Tahun 2012 Tentang Pangan. 